\title{
Sikap Bahasa Guru Sekolah Dasar terhadap Bahasa Indonesia Ragam Tulis Baku
}

\author{
Sri Hapsari Wijayanti ${ }^{1}$, Syarief Darmoyo ${ }^{2}$, Yohanna Claudia Dhian ${ }^{3}$ \\ Fakultas Ekonomi dan Bisnis, Universitas Katolik Atma Jaya, Jakarta ${ }^{1,2}$ \\ Fakultas Pendidikan dan Bahasa, Universitas Katolik Atma Jaya, Jakarta ${ }^{3}$ \\ sri.hapsari@atmajaya.ac.id
}

\begin{abstract}
How to cite (in APA Style): Wijayanti, S.H., Darmoyo, S., \& Dhian, Y.C. (2018). Sikap bahasa guru sekolah dasar terhadap bahasa Indonesia ragam tulis baku. Jurnal Pendidikan Babasa dan Sastra, 18(1),28-43. doi: 10.17509/bs_jpbsp.v18i1.12144
\end{abstract}

Article History: Received (February 11, 2018), Revised (March 3, 2018), Accepted (March 25, 2018)

Journal homepage: http://ejournal.upi.edu./index.php/BS_JPBSP

\begin{abstract}
Abstrak: Pembinaan sikap positif terhadap bahasa Indonesia kepada siswa dilakukan setidaknya oleh guru yang juga memiliki sikap positif terhadap bahasa Indonesia. Penelitian ini bertujuan mengamati sikap bahasa guru SD di Jakarta terhadap bahasa Indonesia tulis baku dan mengungkap apakah ada perbedaan sikap bahasa ditinjau dari status sekolah (swasta dan negeri). Penelitian ini merupakan penelitian deskriptif kualitatif dan kuantitatif. Pengumpulan data dilakukan melalui tes menulis esai, kuesioner, dan wawancara. Kuesioner dibagikan kepada 57 responden guru dari lima wilayah di Jakarta, sedangkan wawancara dilakukan kepada 12 guru. Kuesioner berbentuk skala likert yang memuat pernyataan mengenai tiga komponen sikap, yaitu kognitif, afektif, dan konatif. Penelitian ini menemukan bahwa guru SD di Jakarta memiliki sikap positif terhadap bahasa Indonesia tulis baku. Selain itu, tidak ada perbedaan signifikan sikap bahasa antara guru SD negeri dan SD swasta. Kendati ditemukan memiliki sikap positif terhadap bahasa Indonesia tulisa baku, dalam tulisan guru masih memperlihatkan kekurangan dalam menerapkan aspek kebahasaan.
\end{abstract}

Kata kunci: bahasa Indonesia baku, guru, sikap bahasa, menulis

\section{Language Attitude of Elementary Teachers towards Indonesian Formal Writing}

\begin{abstract}
The fostering of positive attitude toward Indonesian language to the students is done at least by teachers who also have a positive attitude towards the Indonesian language. This study aimed to observe the language attitude of elementary school teachers in Jakarta towards Indonesian formal writing and to reveal whether there are differences in language attitudes in terms of the status of schools (private and public). This study is descriptive qualitative and quantitative. Data collected through essay writing tests, questionnaires, and interviews. Questionnaires were distributed to 57 respondents from five areas in Jakarta, while the interviews were conducted to 12 teachers. Likert scales questionnaire form consist of statements about three components of attitude, namely cognitive, affective, and conative. This study found that elementary school teachers in Jakarta has a positive attitude towards Indonesian formal writing. Additionally, there were no significant differences between the language attitudes of public school teachers and private school teacher of elementary school. Although this study found that the teachers have a positive attitude towards Indonesian formal writing, their writing still showed deficiencies in application of aspects of language.
\end{abstract}

Keywords: formal language, teacher, language attitude, writing 


\section{PENDAHULUAN}

Penelitian tentang sikap bahasa telah menarik perhatian banyak peneliti. Umumnya, penelitian sikap bahasa dalam mengambil konteks pendidikan (formal) dikaitkan dengan bagaimana pendidik berhubungan dengan pemelajar (Frender dan Lambert 1973; Seligman, Tucker, dan Lambert 1972 dalam Fasold, 1984), bagaimana pengaruh sikap bahasa pemelajar terhadap pembelajaran bahasa kedua (Fasold, 1984), dan bagaimana kaitan sikap terhadap hasil belajar (Lambert, 1968 dalam Fasold, 1984). Ada pula yang mengaitkan penelitian sikap bahasa dengan variabel sosial, seperti gender, usia, jenis kelamin, pekerjaan, latar belakang bahasa ibu (Kobayashi, 2002; Wang dan Ladegaard, 2008; Komos dan Csizer, 2008).

Penelitian mengenai sikap bahasa dalam konteks Indonesia banyak menyoroti bahasa Indonesia lisan dan tulis dalam ranah akademik dan nonakademik (lihat Kridalaksana (1980); Gunawaran (1983); Suhardi (1996); Mustakim, 1997; Moeliono (1998) dalam Sugiyono dan Sasangka (2011); Moeliono et al. (2011); Sugiyono dan Sasangka (2011)). Khususnya dalam konteks bahasa Indonesia tulis, penelitian sebelumnya mengamati aspek kosakata baru, istilah, dan tanda baca dengan responden kalangan akademik (guru, dosen, dan mahasiswa). Ada pula yang membandingkan sikap bahasa lisan pemakai terhadap bahasa Indonesia dengan bahasa asing dan bahasa daerah. Hasilnya umumnya menunjukkan bahwa pemakai bahasa di Indonesia menunjukkan sikap positif terhadap bahasa Indonesia.

Meskipun sama-sama menggunakan konteks akademik seperti penelitian sebelumnya, penelitian ini mengamati guru sebagai target penelitian. Guru merupakan profesi yang dapat dijadikan model dalam berbahasa, selain penulis berita (wartawan), penulis naskah iklan, dan pendakwah (Moeliono, et al., 2011; Matanggui dan Arifin, 2014). Guru berperan, antara lain, sebagai pendidik, pengajar, pembimbing, pengelola pembelajaran, model dan teladan, dan pembaharu (inovator) (Daryanto dan Tasrial,
2015). Sikap bahasa guru memengaruhi sikap siswa (Crismore et al., 1996 dalam Tsui dan Bunton, 2000; Ruddyanto, 2011) dan keberhasilan siswa belajar ditentukan oleh kesukaan mereka terhadap apa yang dipelajari, seperti ada hubungan positif antara keberhasilan belajar bahasa kedua di sekolah dan sikap positif pemelajar terhadap bahasa kedua dan penuturnya di lain pihak (Sumarsono, 2000).

Guru, terutama guru sekolah dasar, berperan penting dalam menumbuhkan sikap positif terhadap bahasa Indonesia sejak dini karena "pada jenjang inilah kali pertama pengajaran bahasa Indonesia dilaksanakan secara berencana dan terarah [...] guru dapat menanamkan pengetahuan dasar bahasa Indonesia, menumbuhkan rasa memiliki, mencintai, dan bangga akan bahasa Indonesia pada diri siswa, dan dapat meningkatkan keterampilan berbahasa para siswanya" (Basuki et al., 2015). Sikap bahasa guru memengaruhi sikap siswa (Crismore et al. 1996 dalam Tsui dan Bunton, 2000).

Cara berbahasa siswa ditentukan oleh kebiasaan guru dalam berbahasa di sekolah dan di kelas. "Pemakaian bahasa guru, lebihlebih guru bahasa Indonesia, menjadi model berbahasa bagi murid sekurang-kurangnya sewaktu berada di lingkungan sekolah dan lebih khusus lagi selama kegiatan belajarmengajar berlangsung" (Ruddyanto, 2011, p. 244-245). Karena begitu besar pengaruhnya, guru terlebih dahulu memberi contoh berbahasa Indonesia dengan baik, lisan dan tulis, serta menguasai kaidah-kaidah bahasa Indonesia formal yang berlaku. Dengan kata lain, guru perlu selalu meningkatkan keterampilannya dalam berbahasa yang benar (Matanggui dan Arifin, 2014).

Penanaman dan pembinaan sikap positif terhadap bahasa Indonesia kepada siswa dilakukan setidaknya oleh guru yang juga memiliki sikap positif terhadap bahasa Indonesia. Dalam ranah pendidikan, bahasa yang digunakan guru dan siswa adalah bahasa Indonesia formal atau baku. Tolok ukur kebakuan terdapat pada segi kualitas dan kuantitas yang disepakati bersama. Dalam hal 
ini kebakuan mengacu pada ragam bahasa yang bermutu dan dijunjung tinggi yang digunakan oleh kaum intelektual. Kebakuan mencakup tata bunyi, tata bentukan, kosa kata, dan tata kalimat; dengan demikian, acuan kebakuan adalah Pedoman Ejaan Yang Disempurnakan dan Kamus Besar Bahasa Indonesia (Sumasono, 2009). Dalam tulisan ini, penulis akan (a) mengamati sikap bahasa guru SD di Jakarta terhadap bahasa Indonesia tulis baku; (b) mengungkap ada tidaknya perbedaan sikap bahasa ditinjau dari asal sekolah (swasta dan negeri). Hasil penelitian ini dapat memperkaya kajian sikap bahasa kalangan profesional terdidik perkotaan, yaitu guru yang tinggal di kota besar Jakarta. Penelitian ini penting dilakukan mengingat sikap positif penting ditanamkan bagi generasi muda semenjak dini.

\section{METODE}

Penelitian ini mengunakan desain surveideskriptif dengan mix methods sebagai metode penelitiannya. Pengumpulan data kuantitatif dilakukan dengan tes menulis dan kuesioner, sementara pengumpulan data kualitatif dengan wawancara mendalam. Subjek penelitian ini adalah guru SD di lima wilayah di DKI Jakarta. Pengambilan sampel dilakukan dengan teknik convenience sampling. Responden penelitian ini berjumlah 57 orang, yang terdiri atas 32 guru sekolah dasar swasta (SDS) dan 25 guru sekolah dasar negeri (SDN). Wawancara dilakukan terhadap 12 guru: 6 guru dari SDN dan 6 guru dari SDS.
Kuesioner mengandung 60 item pertanyaan komponen sikap: 22 item pertanyaan komponen kognitif, 26 item pertanyaan komponen afektif, dan 12 item pertanyaan komponen konatif. Skala ini menggunakan lima alternatif jawaban beserta skornya. Jawaban dibagi dalam lima skala, yaitu sangat setuju (SS), setuju (S), netral $(\mathrm{N})$, tidak setuju (TS), dan sangat tidak setuju (STS). Sebelum kuesioner dibagikan kepada responden, dilakukan ujicoba kepada 20 guru. Hasil uji validitas dan reliabilitias terhadap alat ukur tersebut menunjukkan bahwa hanya 18 item pertanyaan komponen kognitif, 16 item pertanyaan komponen afektif, dan 9 item pertanyaan komponen konatif yang valid $(r>0.5, \alpha=0.05)$ dan reliabel (nilai cronbach' alpha $>0.70)$. Adapun wawancara mendalam dilakukan untuk menguatkan kuesioner dan menjaring lebih jauh apa yang belum terungkap dalam kuesioner.

Tolok ukur sikap bahasa diwujudkan dalam rentang indeks 0 sampai 1 . Indeks 0 menunjukkan sikap paling rendah atau negatif, sedangkan indeks 1 menunjukkan sikap positif. Dikatakan bersikap positif apabila guru mempunyai impresi baik, menggunakan bahasa Indonesia dalam ranah tulis baku, dan mau menurunkan penggunaan bahasa itu kepada generasi berikutnya (Sugiyono dan Sasangka, 2011, p. 68). Rentang indeks dalam penelitian ini adalah sebagai berikut (Sumber: Sugiyono dan Sasangka, 2011):

\begin{tabular}{cl} 
Tabel 1. & Rentang Indeks Sikap \\
\hline$<0.2$ & Negatif \\
$0.2-0.4$ & Cukup positif \\
$0.5-0.8$ & Positif \\
$>0.8$ & Sangat positif \\
\hline
\end{tabular}

Seperti yang tertuang dalam kuesioner, pilihan sangat tidak setuju (STS) dikuantifikasi menjadi nilai 1 , tidak setuju (TS) menjadi nilai 2, ragu-ragu atau netral (N) menjadi nilai 3, setuju (S) menjadi nilai 4, dan sangat setuju (SS) menjadi nilai 5. Dalam penghitungan indeks, nilai-nilai hasil kuantifikasi itu dikonversi ke indeks dengan rumus berikut (Sugiyono \& Sasangka, 2011): 


$$
\mathrm{I}=\mathrm{N} / 5
$$

Keterangan:

I - indeks

$\mathrm{N}$ - nilai hasil kuantifikasi

5 - nilai tertinggi dalam skala likert

Dengan menggunakan rumus di atas, data berupa angka indeks dengan rentang 0 sampai 1. Sementara itu, indeks per komponen (Ik) sikap adalah rata-rata indeks dari semua butir pertanyaan dalam komponen itu. Rumus menghitung indeks per komponen adalah (Sugiyono dan Sasangka, 2011)

\section{Keterangan:}

$$
\mathrm{Ik}=\Sigma \mathrm{I}(\dagger) / \mathrm{N}(\dagger)
$$

$\mathrm{Ik}$ - indeks per komponen

$\mathrm{I}(\dagger)$ - indeks butir pertanyaan

$\mathrm{N}(\dagger)$ - jumlah butir yang relevan dengan komponen itu

Indeks sikap bahasa dihitung dengan rumus (Sugiyono dan Sasangka, 2011):

$$
\mathrm{Ik}=\Sigma \mathrm{I}(\mathrm{k}) / 3
$$

Keterangan:

$\mathrm{I}(\mathrm{k})$ - indeks komponen

3 - jumlah komponen sikap dalam penelitian ini (kognitif, afektif, konatif)

Data kuantitatif penelitian ini dianalisis dengan teknik statistika deskriptif berupa crosstabs, range, mean, standard deviation, pearson product moment, cronbach' alpha, dan independentsamples t-test. Crosstabs digunakan untuk mendeskripsikan profil responden. Range, mean, dan standard deviation digunakan untuk mendeskripsikan variabel-variabel sikap. Pearson product moment dan cronbach' alpha masing-masing digunakan untuk uji validitas dan reliabilitas instrumen penelitian. Independent-samples t-test digunakan untuk membandingkan selisih mean skor indeks sikap guru SDN dan guru SDS. Adapun taraf signifikansi $(\alpha)$ yang digunakan dalam uji validitas sebesar 5\% dan dalam independentsamples t-test sebesar $10 \%$, sementara nilai cronbach' alpha yang digunakan dalam uji reliabilitas minimal 0.70. Data kualitatif penelitian ini, yang berupa hasil wawancara, dianalisis dengan teknik thematic analysis. Langkah-langkah yang ditempuh adalah mentranskrip verbatim wawancara, mengkoding, mengategorisasikan isi berdasarkan kesamaan makna, mereduksi data, dan menginterpretasikan data secara ekstensif dan mendalam (Moeliono, 2013). Tabel 2 memperlihatkan kategori skor ratarata dan distribusi frekuensi kemampuan guru yang digunakan sebagai acuan dalam analisis.

Tabel 2. Kategori Rata-Rata dan Distribusi Frekuensi Kemampuan Menulis

\begin{tabular}{llcllll}
\hline \multirow{2}{*}{ Kategori } & \multicolumn{3}{c}{ Total } & \multicolumn{3}{c}{ Nilai } \\
& \multicolumn{3}{c}{ Per Aspek } \\
\hline Sangat baik & 80 & - & 100 & 16 & - & 20 \\
Baik & 60 & - & 79 & 12 & - & 15 \\
Cukup & 40 & - & 59 & 8 & - & 11 \\
Kurang & 20 & - & 39 & 4 & - & 7 \\
Sangat kurang & 0 & - & 19 & 0 & - & 3 \\
\hline
\end{tabular}




\section{HASIL DAN PEMBAHASAN}

Sebelum memaparkan hasil penelitian, di bawah ini diuraikan temuan mengenai gambaran responden penelitian. Berdasarkan hasil kuesioner, diketahui profil guru sebagai berikut. Menurut jenis kelamin, dari 57 guru yang disurvei, guru perempuan (82.5\%) lebih banyak daripada guru laki-laki (17.5\%). Perbedaan persentase guru perempuan di SDN lebih besar daripada di SDS, perbedaannya terpaut $12.2 \%$. Hal itu dapat dilihat dalam Tabel 3.

Tabel 3. Profil Responden berdasarkan Jenis Kelamin

\begin{tabular}{lcccccc}
\hline & \multicolumn{2}{c}{ SD Negeri } & \multicolumn{2}{c}{ SD Swasta } & \multicolumn{2}{c}{ Total } \\
\cline { 2 - 7 } & $\mathrm{F}$ & $\%$ & $\mathrm{f}$ & $\%$ & $\mathrm{f}$ & $\%$ \\
\hline Laki-laki & 3 & 11.1 & 7 & 23.3 & 10 & 17.5 \\
Perempuan & 24 & $\mathbf{8 8 . 9}$ & 32 & $\mathbf{7 6 . 7}$ & 47 & $\mathbf{8 2 . 5}$ \\
\hline & 27 & 100.0 & 30 & 100.0 & 57 & 100.0 \\
\hline
\end{tabular}

Usia responden guru bervariasi. Seperti tampak pada Tabel 4, guru yang berusia 46--55 tahun ada 22 orang $(38,6 \%), 36--45$ tahun ada 14 orang $(24.6 \%)$, dan $25--35$ tahun ada 13 orang $(22.8 \%)$. Sementara itu, guru yang berusia di atas 55 tahun hanya 8 orang $(14 \%)$. Kelompok guru yang berusia 46--55 tahun lebih banyak yang mengajar di SDN (44.4\%) daripada guru yang mengajar di SDS (33.3\%). Sebaliknya, kelompok guru yang berusia 36--
45 tahun lebih banyak yang mengajar di SDS $(36.7 \%)$ daripada di SDN (11.1\%). Untuk kelompok guru yang berusia 25--35 tahun, jumlah guru yang mengajar di SDN dan SDS hampir sama, masing-masing $22.2 \%$ dan $23.3 \%$. Sementara itu, kelompok guru yang berusia di atas 55 tahun jauh lebih banyak yang mengajar di SDN (22.2\%) dibandingkan guru yang mengajar di SDS (6.7\%).

Tabel 4. Profil Responden berdasarkan Usia

\begin{tabular}{lcccccc}
\hline & \multicolumn{2}{c}{ SD Negeri } & \multicolumn{2}{c}{ SD Swasta } & \multicolumn{2}{c}{ Total } \\
\cline { 2 - 7 } & $\mathrm{f}$ & $\%$ & $\mathrm{f}$ & $\%$ & $\mathrm{f}$ & $\%$ \\
\hline $25-35$ tahun & 6 & 22.2 & 7 & 23.3 & 13 & 22.8 \\
$36-45$ tahun & 3 & 11.1 & 11 & $\mathbf{3 6 . 7}$ & 14 & 24.6 \\
$46-55$ tahun & 12 & $\mathbf{4 4 . 4}$ & 10 & 33.3 & 22 & $\mathbf{3 8 . 6}$ \\
Lebih dari 55 tahun & 6 & $\mathbf{2 2 . 2}$ & 2 & 6.7 & 8 & 14.0 \\
\hline & 27 & 100.0 & 30 & 100.0 & 57 & 100.0 \\
\hline
\end{tabular}

Latar belakang pendidikan sebagian besar guru SD adalah S-1 (93\%), tetapi ada juga S-2 dan SMA, masing-masing 1.8\% dan $5.3 \%$. Jumlah guru yang bergelar S-1 di SDN sebanyak 26 orang $(96.3 \%)$, sementara di SDS sebanyak 27 orang $(90.0 \%)$. Guru yang bergelar S-2 hanya terdapat di SDN, sedangkan yang lulusan SMA hanya ada di SDS (lihat Tabel 5). 
Tabel 5. Profil Responden berdasarkan Tingkat Pendidikan

\begin{tabular}{|c|c|c|c|c|c|c|}
\hline & \multicolumn{2}{|c|}{ SD Negeri } & \multicolumn{2}{|c|}{ SD Swasta } & \multicolumn{2}{|c|}{ Total } \\
\hline & $\mathrm{f}$ & $\%$ & $\mathrm{f}$ & $\%$ & $\mathrm{f}$ & $\%$ \\
\hline SMA & 0 & .0 & 3 & 10.0 & 3 & 5.3 \\
\hline S-1 & 26 & 96.3 & 27 & 90.0 & 53 & 93.0 \\
\hline S-2 & 1 & 3.7 & 0 & .0 & 1 & 1.8 \\
\hline & 27 & 100.0 & 30 & 100.0 & 57 & 100.0 \\
\hline
\end{tabular}

Dari 53 responden yang memiliki latar pendidikan S-1, hanya 38 guru yang menyebutkan latar belakang jurusan yang beragam, yaitu pendidikan, nonpendidikan, pendidikan keagamaan, dan lainnya. Tabel 6 menunjukkan latar belakang jurusan pendidikan guru. Dari tabel tersebut diketahui bahwa sebagian besar guru $(73.7 \%)$ memiliki latar belakang jurusan pendidikan. Lainnya, memiliki latar berlakang nonpendidikan $(10.5 \%)$, pendidikan keagamaan $(7.9 \%)$, dan lainnya $(7.9 \%)$. Yang tergolong jurusan pendidikan adalah Pendidikan Guru Sekolah Dasar (PGSD), Pendidikan Kewarganegaran, Pendidikan Matematika, Manajemen Pendidikan, dan sebagainya. Dari semua jurusan tersebut, guru terbanyak berasal dari PGSD (17 orang) dari 38 responden yang menjawab latara belakang pendidikan. Sementara itu, sisanya termasuk jurusan nonpendidikan guru, seperti Sastra Inggris, Bahasa dan Sastra Indonesia, dan jurusan Pendidikan Keagamaan, khususnya Tarbiyah dan Dakwah Agama Islam (DAI).

Dalam Tabel 6 juga tampak bahwa jika ditelusuri lebih jauh latar belakang jurusan menurut jenis sekolah, persentase guru yang memiliki latar belakang jurusan pendidikan lebih besar di SDN (83.3\%) daripada di SDS $(65.0 \%)$, persentase jurusan pendidikan keagamaan lebih besar di SDS (10.0\%) daripada di SDN (5.6\%). Sementara itu, persentase guru yang memiliki latar belakang jurusan nonpendidikan di SDN tidak jauh berbeda dengan persentase yang di SDS, masing-masing $11.1 \%$ dan $10.0 \%$.

Tabel 6. Profil Responden berdasarkan Latar Belakang Pendidikan

\begin{tabular}{lllllll}
\hline & \multicolumn{2}{l}{ SD Negeri } & \multicolumn{2}{l}{ SD Swasta } & \multicolumn{2}{l}{ Total } \\
\cline { 2 - 7 } & $\mathrm{f}$ & $\%$ & $\mathrm{f}$ & $\%$ & $\mathrm{f}$ & $\%$ \\
\hline Pendidikan & 15 & $\mathbf{8 3 . 3}$ & 13 & 65.0 & 28 & $\mathbf{7 3 . 7}$ \\
Nonpendidikan & 2 & 11.1 & 4 & 10.0 & 4 & 10.5 \\
Pendidikan Keagamaan & 1 & 5.6 & 2 & $\mathbf{1 0 . 0}$ & 3 & 7.9 \\
Lainnya & 0 & .0 & 3 & 15.0 & 3 & 7.9 \\
\hline & 18 & 100.0 & 20 & 100.0 & 38 & 100.0 \\
\hline
\end{tabular}

Dari segi pengalaman mengajar, guru memiliki pengalaman mengajar yang sangat beragam: kurang dari 5 tahun (19.3\%), 6--10 tahun (8.8\%), 11-- 15 tahun (15.8\%) dan 16-20 tahun (12.3\%), dan lebih dari 20 tahun (43.9\%). Guru yang memiliki pengalaman mengajar lebih dari 20 tahun dan antara 11 sampai 15 tahun, persentasenya lebih besar di SDN daripada di SDS, sementara guru yang memiliki pengalaman mengajar kurang dari 5 tahun, 16--20 tahun, dan 6--10 tahun persentasenya lebih besar di SDS daripada di SDN (lihat Tabel 7). 
Jurnal Pendidikan Bahasa dan Sastra, Volume 18, Nomor 1, April 2018, pp. 28-43

Tabel 7. Profil Responden berdasarkan Pengalaman Mengajar

\begin{tabular}{lcccccc}
\hline & \multicolumn{2}{c}{ SD Negeri } & \multicolumn{2}{c}{ SD Swasta } & \multicolumn{2}{c}{ Total } \\
\cline { 2 - 7 } & $\mathrm{f}$ & $\%$ & $\mathrm{f}$ & $\%$ & $\mathrm{f}$ & $\%$ \\
\hline Kurang dari 5 tahun & 4 & 14.8 & 7 & $\mathbf{2 3 . 3}$ & 11 & 19.3 \\
6 - 10 tahun & 2 & 7.4 & 3 & $\mathbf{1 0 . 0}$ & 5 & 8.8 \\
$11-15$ tahun & 5 & $\mathbf{1 8 . 5}$ & 4 & 13.3 & 9 & 15.8 \\
$16-20$ tahun & 1 & 3.7 & 6 & $\mathbf{2 0 . 0}$ & 7 & 12.3 \\
Lebih dari 20 tahun & 15 & $\mathbf{5 5 . 6}$ & 10 & 33.3 & 25 & $\mathbf{4 3 . 9}$ \\
\hline & 27 & 100.0 & 30 & 100.0 & 57 & 100.0 \\
\hline
\end{tabular}

Ditilik dari bahasa yang digunakan, separuh guru memiliki bahasa ibu bahasa Indonesia (56.1\%), sisanya $(43.9 \%)$ memiliki bahasa ibu bahasa daerah. Persentase guru yang memiliki bahasa ibu bahasa Indonesia dan guru yang memiliki bahasa ibu bahasa daerah tidak jauh berbeda baik di SDN maupun di SDS sebagaimana tampak pada Tabel 8.

Tabel 8. Profil Responden berdasarkan Bahasa Ibu

\begin{tabular}{lcccccc}
\hline & \multicolumn{2}{c}{ SD Negeri } & \multicolumn{2}{c}{ SD Swasta } & \multicolumn{2}{c}{ Total } \\
\cline { 2 - 7 } & $\mathrm{f}$ & $\%$ & $\mathrm{f}$ & $\%$ & $\mathrm{f}$ & $\%$ \\
\hline Bahasa Daerah & 11 & 40.7 & 14 & 46.7 & 25 & 43.9 \\
Bahasa Indonesia & 16 & $\mathbf{5 9 . 3}$ & 16 & $\mathbf{5 3 . 3}$ & 32 & $\mathbf{5 6 . 1}$ \\
\hline & 27 & 100.0 & 30 & 100.0 & 57 & 100.0 \\
\hline
\end{tabular}

Jika ditelaah lebih lanjut pada kelompok guru yang berbahasa ibu bahasa daerah, sebanyak 23 guru menyebutkan bahasa ibu mereka adalah bahasa Jawa (43.5\%), bahasa Batak (30.4\%), dan bahasa Sunda (26.1\%). Guru yang berbahasa ibu bahasa Jawa dan Sunda lebih banyak mengajar di SDS daripada di SDN; sebaliknya guru yang berbahasa ibu bahasa Batak lebih banyak mengajar di SDN daripada di SDS. Hal ini dapat dilihat pada Tabel 9.

Tabel 9. Profil Responden berdasarkan Jenis Bahasa Ibu

\begin{tabular}{ccccccc}
\hline & \multicolumn{2}{c}{ SD Negeri } & \multicolumn{2}{c}{ SD Swasta } & \multicolumn{2}{c}{ Total } \\
\cline { 2 - 7 } & $\mathrm{f}$ & $\%$ & $\mathrm{f}$ & $\%$ & $\mathrm{f}$ & $\%$ \\
\hline Bahasa Jawa & 4 & 36.4 & 6 & $\mathbf{5 0 . 0}$ & 10 & $\mathbf{4 3 . 5}$ \\
Bahasa Sunda & 2 & 18.2 & 4 & $\mathbf{3 3 . 3}$ & 6 & 26.1 \\
Bahasa Batak & 5 & $\mathbf{4 5 . 5}$ & 2 & 16.7 & 7 & 30.4 \\
\hline & 11 & 100.0 & 12 & 100.0 & 23 & 100.0 \\
\hline
\end{tabular}

Survei ini mengungkap bahwa bahasa yang paling dikuasai guru selain bahasa Indonesia, berturut-turut adalah bahasa daerah (79.2\%), diikuti bahasa Inggris (22.\%), dan bahasa Arab (6.15\%) (lihat Tabel 10). Guru yang menguasai bahasa daerah lebih banyak di SDS $(85.2 \%)$ daripada di SDN (73.1\%). Guru yang menguasai bahasa Inggris lebih banyak di SDN (26.9\%) daripada di SDS (16.7\%). Dari survei ini juga diketahui ada dua guru yang menguasai lebih dari satu bahasa, yaitu satu orang menguasai bahasa Inggris dan bahasa daerah (Jawa) dan satunya lagi menguasai bahasa Arab dan bahasa daerah (Sunda). 
Tabel 10. Profil Responden berdasarkan Bahasa yang Dikuasai Guru

Selain Bahasa Indonesia

\begin{tabular}{lcccccl}
\hline & \multicolumn{2}{c}{ SD Negeri } & \multicolumn{2}{c}{ SD Swasta } & Total \\
& $\mathrm{f}$ & $\%$ & $\mathrm{f}$ & $\%$ & $\mathrm{f}$ & $\%$ \\
\hline Inggris & 7 & $\mathbf{2 6 . 9}$ & 4 & 16.7 & 11 & 22.0 \\
Arab & 0 & 0.0 & 3 & 13.0 & 3 & 6.1 \\
Mandarin & 0 & 0.0 & 0 & 0.0 & 0 & 0.0 \\
Daerah & 19 & $\mathbf{7 3 . 1}$ & 23 & $\mathbf{8 5 . 2}$ & 42 & $\mathbf{7 9 . 2}$ \\
\hline
\end{tabular}

\section{Sikap Bahasa Guru SD di Jakarta}

\section{terhadap Bahasa Indonesia Tulis Baku}

Dalam Tabel 11 diketahui bahwa guru SD memiliki sikap yang positif terhadap bahasa Indonesia. Indeks sikap guru terentang antara 0.6 dan 1.0 dengan mean sebesar 0.780 serta standar deviasi berkisar 0.06. Jika dilihat per komponen sikap, indeks kognitif, afektif, dan konatif terentang antara 0.6 dan

1.0 dengan mean kognitif sebesar 0.790 , afektif sebesar 0.815 , dan konatif sebesar 0.729 , serta standar deviasi kurang dari 0.010. Hal ini menunjukkan bahwa guru memiliki sikap yang positif pada komponen kognitif dan konatif dan sikap yang sangat positif pada komponen afektif

Tabel 11. Sikap Guru SD terhadap Bahasa Indonesia Tulis Baku

\begin{tabular}{lccccc}
\hline & $\mathrm{N}$ & Minimum & Maximum & Mean & Std. Deviation \\
\hline Sikap & 49 & .6 & 1.0 & .780 & .0678 \\
Kognitif & 53 & .7 & .9 & .790 & .0759 \\
Afektif & 53 & .7 & 1.0 & .815 & .0730 \\
Konatif & 57 & .6 & 1.0 & .729 & .0932 \\
\hline
\end{tabular}

Dari temuan ini dapat dikatakan guru SD di Jakarta sudah memiliki sikap positif terhadap bahasa Indonesia tulis baku. Hal ini sudah baik karena memang jenjang sekolah dasar merupakan fondasi dalam membekali siswa dengan sikap positif terhadap pelajaran bahasa Indonesia beserta keterampilannya sehingga siswa lebih mudah menyelesaikan studinya (Basuki et al., 2015). Sikap positif dapat dinyatakan dari perilaku kesetiaan terhadap bahasa (language loyality) yang mendorong masyarakat bahasa mempertahankan bahasanya dan mencegah pengaruh bahasa lain, kebanggaan bahasa (language pride) yang mendorong orang mengembangkan bahasa dan menggunakannya sebagai lambang identitas dan kesatuan masyarakat; kesadaran akan norma (awareness of the norm) yang mendorong masyarakat menggunakan bahasa dengan cermat dan santun (Garvin dan Mathiot, 1968 dalam Sukma, 2015).

Secara kognitif umumnya guru SD di Jakarta sudah memahami konsep bahasa Indonesia tulis baku dan mampu memberikan contoh-contohnya. Dari wawancara, guru mengakui adanya kaidah-kadiah dalam menulis, seperti tidak boleh menggunakan bahasa informal atau bahasa gaul, menggunakan kata-kata yang baku dan tanda baca yang tepat. Mereka juga memperhatikan bahasa Indonesia yang ditulis siswa dan mengoreksinya jika ada yang kurang tepat. Akan tetapi, sayangnya, jika diamati dari tulisan guru, bahasa Indonesia tulis guru belum dapat dijadikan contoh karena masih belum menggunakan bahasa Indonsia tulis formal.

Penelitian ini menemukan bahwa tidak semua guru mampu menulis. Guru mengakui kurang menyukai menulis karena 
mengalami kesulitan dalam mengembangkan ide.

....ide Pak....ide tadi yang saya bilang kalo mengarang itu harus baku itu biasanya idenya itu yang ...idenya seperti apa sih ... kita misalkan temanya seperti tadi pendidikan nah dari dari tema itu kita harus pinter tentukan dulu judulnya apa ...dari judulnya nah ini apa yang berhubungan dengan judul itu ... jadi ide ...terus hambatan yang kedua .... mengembangkan dari satu kalimat itu menjadi satu paragraf..... (laki-laki, SDS)

Dilaporkan bahwa penguasaan guru SD terhadap materi ajar tergolong kompetensi yang paling tertinggal ketika dilakukan uji kompetensi (Kompas, 8 Juli 2015). Hal ini merupakan hambatan tersendiri mengingat guru SD harus menguasai semua bidang studi dan diakui guru SDN di Jakarta bahwa ia kurang mendapat kesempatan mengikuti pelatihan berkenaan dengan pendalaman materi ajar. Pelatihan yang didapat justru lebih banyak berkaitan dengan administrasi kegiatan belajar mengajar (KBM).

Saya guru honorer bersertifikasi (berlatar belakang ekonomi-pen). Saya dikarantina untuk mengikuti PLPG. Di situ selama 10 hari dilatih hanya bagaimana mengajar yang benar, seperti itu, tidak menulis, bagaimana cara BI yang benar, menjadi guru yang baik seperti apa. Untuk administrasinya lebih banyak guru diajarkan cara mengisi administrasi guru dengan segala macam BPK-nya., daftar absensi begini begini yang lebih baik lagi. Kalau yang lain-lain sih ... (perempuan, SDN)

Pelatihan guru diberikan cara menulis soal, cara memberikan jawaban panjang. Misalnya sebutkan 4 daerah yang diduduki Jepang. Jawaban harus panjang tidak boleh dalam bentuk angka (perempuan, SDS)

Guru menunjukkan sikap sangat positif pada aspek afektif (lihat Tabel 11). Hal ini tampak dari perilaku guru yang merasa prihatin akan kondisi pemakaian bahasa siswa zaman sekarang yang banyak menyingkat kata. Guru mengakui hal itu akibat pengaruh perkembangan teknologi yang makin canggih.

Penggunaan bahasa Indonesia saat ini mengalami kemunduran ...penyebabnya adalah budaya-budaya asing....yang kedua adalah tontonan-tontonan yang mempertontonkan bagaimana penggunaan bahasanya itu lebih banyak penggunaan bahasa Indonesia yang nonbaku....bahasa-bahasa gaul ....bahasabahasa dalam kehidupan seharihari...sehingga kadang-kadang di murid saya sendiri muncul bahasa-bahasa yang tidak ada dalam konteks bahasa Indonesia ..seperti baper lah..... kemudian gaje lah ... itu jadi mengalami sedikit kemunduran .... (laki-laki, SDS)

Maraknya pemakaian gawai, kentalnya pengaruh internet dan penggunaan bahasa asing di lingkungan siswa, serta kurang adanya dukungan dari keluarga merupakan faktorfaktor yang menyebabkan guru merasa kurang mendapat dukungan orangtua dalam mendidik dan mengajarkan siswa untuk berbahasa dengan baik. Sikap positif guru dinyatakan dengan kemauannya mendorong siswa untuk menggunakan bahasa Indonesia baku, untuk bangga terhadap bahasa Indonesia, dan ikut membina bahasa Indonesia.

... bahasa Indonesia tuh terkontaminasinya tuh karena kemajuan teknologi itu kali ya...apa namanya...era globalisasi...itu juga semua unsur-unsur kata keluar begitu aja kan...dengan mudahnya lewat dunia maya kayak gitu lewat gadget kan...setiap pribadi masingmasing bebas...mau ngetik dengan bentuk apa aja, kadang-kadang huruf besar, kecil dicampur aduk sementara penggunaan gadget itu, dari anak-anak kecil aja sudah menggunakan gadget...jadi satu masalahnya...itu tadi ya ...apa namanya Pak...pengaruh dari dunia maya...itu tadi internet....terus kedua dari keluarga, jadi orangtua kayaknya engga ada saringan gitu, tidak diawasi gitu...sementara dari pihak sekolah guru itu sudah berusaha 
mengajarkan bahasa Indonesia yang benar... (perempuan, SDN)

Bahasa Indonesia saat ini sudah rusak dan tidak digunakan dengan baik dan benar. Bahkan anak zaman sekarang karena didukung orangtua yang lebih bangga anaknya mampu berbahasa asing, sering mencampuradukkan bahasa Indonesia dengan bahasa asing. Padahal kultur berbahasa Indonesia harus dibangun dari keluarga, sekolah, dan masyarakat sekitar (laki-laki, SDN)

Sikap positif tampak pula ketika guru memperbaiki tulisan siswa yang dianggapnya kurang tepat, seperti tidak menggunakan huruf kapital atau menggunakan bahasa gaul. Hal ini menunjukkan bahwa guru memperhatikan atau menyadari kaidah-kaidah bahasa Indonesia tulis, yakni pemakaian ejaan yang benar, kata yang baku, dan kalimat yang gramatikal.

Saya kan suka ni setelah anak-anak bikin karangannya saya suruh maju ke depan. Nanti disuruh dengar teman-temannya nanti saya iniin. Kalau bahasanya ini, intinya saya cerita kembali kan. Saya selalu perbaiki kalau cara tulisnya salah. Misalnya harusnya huruf besar dia tulis huruf kecil. Itu spontan $\mathrm{Bu}$, saya langsung ini saya kalau koreksi kalau dia salah saya langsung tulisin yang benernya... (perempuan, SDS)

\section{Meskipun demikian, guru menunjukkan ketidakyakinannya dalam mengajarkan bahasa Indonesia.}

T : Yang Ibu perhatikan apa dengan tulisan anak-anak ini

J : : Apa ya? Cara dia berbicara dengan tulisan. Oh saya suka anak ini bisa merangkai kalimat demi kalimat dia nyambung, ceritanya berurutan, kan ada yang loncatloncat.

T : He eh. Kalau dari segi ejaannya gitu. Ibu perhatikan juga gak?

J : Perhatikan. Cuma kadang anakanak itu gitu, cuma yang susah itu huruf kapital tidak paham. Saya sendiri saja gitu. Penjedahan yang bener itu gimana gitu.

$$
\begin{array}{ll}
\mathrm{T} & : \text { Yang mana maksudnya? } \\
\mathrm{J} & : \text { Penjedahan (penjedaan-pen) } \\
\mathrm{T} & : \text { Oh } \\
\mathrm{J} & : \text { Ketika koma harusnya di mana. } \\
& \begin{array}{l}
\text { Saya saja susah } \\
\text { (perempuan, SDS) }
\end{array}
\end{array}
$$

Di sisi lain guru mengamati kesalahan berbahasa tulis yang berulang kali ditemukan di dalam tulisan siswa dituding bersumber dari ke guru yang mengajar di kelas bawah. Guru yang mengajar di SD kelas bawah tidak menghiraukan kesalahan tulisan siswa sehingga siswa tidak menyadari ada yang keliru dalam menggunakan unsur-unsur bahasa.

...ini loh nak nulis jangan lupa ya huruf besar, tanda baca, jangan lupa nama orang itu huruf besar, nama-nama negara, dan lain sebagainya yang pentingpenting....jangan lupa tanda baca, koma, titik jangan lupa...itu kalimat apa jangan lupa gitu...sebenernya guru udah mengajarkan seperti itu gitu, tapi kenapa anak ngga bisa ngelakuinnya gitu .... entar katanya lupa, Bu...masa sih lupa ....kadang nih huruf besar ...ada di tengah-tengah misalnya siapa...siapakah nama anak itu.....dia bener nih di sini SIAPA ..... nama "N" nya besar kan ngga ada urusannya...anak itu "I" nya ... iya ada di tengah-tengah kata kan eh kalimat ... tapi itu bukan yang menggunakan huruf kapital ... jadi turun naik, turun naik...huruf besar, huruf kecil...huruf besar, huruf kecil ....coba benerinnya dari mana tuh...ngebetulinnya sebenernya dari awal...sementara kelasnya udah di kelas berapa...memang harus dari bawah...tapi saya rasa guru yang bawah pun sudah mengajarkan hal itu gitu huruf besar sambung, huruf besar cetak gitu... udah, udah diajarkan nulis sambung gitu tapi entah,.....berarti kan dari anak dan lingkungan rumah menurut saya gitu .... (perempuan, SDN)

Guru menyadari kesalahan yang didiamkan saja akan berakar hingga siswa duduk di jenjang pendidikan yang lebih tinggi. Karena itu, kejelian guru untuk menegur, 
mengingatkan, memperbaiki bahasa tulis siswa sudah seharusnya dimulai di jenjang pendidikan dasar.

karena mereka kan belajar dari guru, dari sekolah, apa yang diajarkan guru melekat pada anak...kalo kita ngajarin anak "yang" aja disingkat mereka ikut yang disingkat tapi kalo kita sudah ajarin "yang" jangan disingkat, engga boleh....nah tuh tanda itu mereka suka sering kata ulang umpamanya anak-anak mereka sering kasih tulis 2 (dua) juga engga boleh...itu juga begitu Pak...mesti kita arahin satu-satu memang...kalo gurunya yang enggak teliti terhadap anak-anak tulisannya terus sampe SMP bisa begitu...umpamamya gak mau males menulis, kalo ada kata yang sama dia tinggal tanda-tandain begitu...itu kalau kitanya, gurunya engga teliti, didiemin aja, engga mau diganti, seterusnya mereka akan begitu, ngikutin...ya jadi harus dari awal, juga tulisan, kadang-kadang kalo lagi bahasa Indonesia tulisannya, huruf besarnya... ini kalau di awal huruf besar...ini nama kota huruf depannya harus dibesarkan tapi kalo mereka engga...itu ya terus SMP akan berlanjut, engga ngerti mana yang pake huruf besar, mana yang engga.... (perempuan,SDS)

Mengajarkan menulis sama sulitnya dengan mengajarkan matematika. Setidaknya demikian pendapat guru berikut ini ketika mengajarkan paragraf.

Anak SD itu mereka terlalu polos. "Nak, kalo menulis paragraf itu menjorok ke dalam kan saya kasih ini nih panah... Nak, di sini jangaan di sini. Setelah kalimat kedua di sini nanti samain gitu" jadi saya mengajar bahasa Indonesia itu memang kadarnya sama dengan matematika, samasama susahnya yang tadi saya sampaikan bahwa mereka itu meremehkan, tapi enggak ngerti.. kalo meremehkan ngerti mah mendingan itu... (laki-laki, SDS)

Guru SD di Jakarta sudah memenuhi kualifikasi akademik (minimal S-1) seperti yang diundangkan dalam UU No. 14 Tahun 2005. Namun, berdasarkan temuan Jakaria (2014), dari sejumlah 1.501.236 guru SD negeri dan swasta di Indonesia, masih ditemukan 29.3\% ketidaksesuaian antara latar belakang pendidikan dan mata pelajaran yang diampu. Karena itulah, tidak mengherankan apabila guru kurang memahami kaidah-kaidah menulis bahasa Indonesia yang baik dan benar, seperti penulisan ejaan dan kalimat.

Pengalaman saya sejak menjadi guru dalam beberapa bidang studi bahwa bahasa Indonesialah yang paling tidak saya sukai, sementara pelajaran yang lain boleh-boleh saja. Oleh karena itu, terus terang saya sering mengalami kesulitan dalam mengajarkan pelajaran Bahasa Indonesia dalam menulis, mengartikan kata-kata sulit terlebih-lebih disuruh membuat sebuah karangan, itu pekerjaan yang menyulitkan bagi saya. Oleh karena itu, dalam mengajarkan Bahasa Indonesia sangat menyulitkan kepada siswa-siswa saya. (perempuan, SDS)

Dalam berbahasa, konteks berperan penting. Dalam konteks bahasa tulis formal, bahasa yang digunakan pun haruslah formal. Hal itu disadari guru bahwa dalam mengajar ia menggunakan bahasa Indonesia formal sebagai bahasa pengantar. Semua guru sangat menyadari bahwa bahasa Indonesia yang digunakan menjadi contoh bagi siswanya. Hal tersebut diperkuat pendapat guru dalam penelitian ini bahwa guru merupakan model dalam berbahasa dan berperilaku.

...kita kan sebagai teladan, Pak, jadi apa pun yang diucapkan guru di depan pada saat mengajar itu secara otomatis, secara tidak sadar itu nanti akan diikuti oleh siswa terutama bagi guru yang mengajar kelas kecil, kelas satu, dua, tiga, secara otomatis mereka akan melihat oh guruku ngomongnya seperti ini, jadi mereka akan menirukan...sama juga saya menghadapi kelas enam ini juga seperti itu.... jadi sikap saya, cara bicara saya itu ada murid saya yang menirukan ...jadi kalo saya keceplosan kadang-kadang mengeluarkan bahasa yang tidak baku mereka juga ikutikutan ...tetapi kalo saya membiasakan dengan bahasa yang baku mereka dengan 
sendirinya terbiasa untuk ikut....karena memang sebagian besar waktu ya dihabiskan di sekolah ... (laki-laki, SDS)

Pendidikan bahasa Indonesia di tingkat dasar penting sebagai dasar bagi siswa agar terampil menggunakan bahasa sebagai alat komunikasi. Karena itu, pijakan berbahasa yang baik, benar, dan santun patut diajarkan di jenjang tersebut. Hal ini berarti siswa perlu mendapat teladan dari guru yang mengajar di kelas khususnya. Karena tujuan utama belajar bahasa Indonesia adalah untuk terampil berbahasa Indonesia, guru seyogianya mempunyai kompetensi sebagai model dalam menyampaikan materi bahasa (Asih, 2016). Hal ini disadari semua guru yang menjadi responden penelitian ini. Guru SD di Jakarta menjadi panutan bagi siswa dalam berperilaku berbahasa. Mereka senantiasa menasihati, menegur siswa jika berbicara tidak pantas atau jika menggunakan bahasa gaul dan ketika siswa menulis tidak sesuai dengan kaidah bahasa baku. Hal ini tampak dalam tulisan dan hasil wawancara dengan guru.

Anak-anak itu ibarat kertas kosong. Misalnya huruf A kata guru begini. Kata orang-orang tua begini. Gak mau $\mathrm{Bu}$, dia mau dari guru. Itu namanya mempegaruhi luar biasa, Bu. Percaya sama guru. (perempuan, SDS)

Bahasa guru sangat berpengaruh. Guru sosok yang ditiru. 90\% anak dipengaruhi oleh guru. Kalau ada perbedaan antara guru dan orangtua, anak akan ikut ke guru. Jadi bahasa Indonesia yang baik perlu ditanamkan kepada siswa. (perempuan,SDS)

Setiap kali saya mengajar bahasa Indonesia selalu diawali dengan perintah,"Janganlah lupa tanda bacanya!" begitulah selalu.

Tetapi kenyataannya di lapangan masih banyak siswa melakukan kesalahan. Tidak menggunakan huruf besar di awal kalimat, nama orang dan lain-lain, tanda baca koma titik, tanya dan perintah. Jangankan menanamkan siswa untuk menulis dengan ejaan yang benar, menulis hari, tanggal yang selalu saya wajibkan saja lupa, lupa dan lupa. (perempuan,SDN)

Kesetiaan guru SD di Jakarta dalam menggunakan bahasa Indonesia tulis diperlihatkan dengan tidak banyak ditemui interferensi dari bahasa asing atau daerah. Hal ini didukung bahwa 56,1\% guru berbahasa ibu bahasa Indonesia (lihat Tabel 8). Rasa bangga berbahasa dibuktikan dengan menjunjung tinggi bahasa Indonesia melalui imbauan dan pemberian contoh kepada siswa. Selain itu, kepatuhan pada norma-norma bahasa diperlihatkan guru dalam memperbaiki kesalahan bahasa Indonesia yang digunakan siswa dan kesadaran guru ketika menulis. Guru yang memiliki sikap positif seperti itu dapat menjadi model dalam pembelajaran bahasa Indonesia sehingga dapat memotivasi siswa untuk peduli menggunakan bahasa Indoesia dan memiliki sikap positif terhadap bahasa Indonesia (Suroso, 2015). Meskipun terbukti memiliki sikap positif, guru dalam penelitian ini masih memerlukan bimbingan, khususnya dalam menulis.

Penelitian ini menunjukkan bahwa meskipun $73.7 \%$ guru bergelar S-1 dari jurusan pendidikan (Tabel 6), guru masih belum menguasai bagaimana mengembangkan ide dan meramu ide dalam penalaran yang baik dengan penggunaan aspek-aspek bahasa yang tepat. Guru ditilik dari tulisan tampak masih lemah dalam aspek ejaan meskipun guru mengakui memperhatikan pemakaian ejaan dalam tulisan siswa, di samping pemakaian bentuk kata dan pilihan katanya. Namun, dalam wawancara tidak terpajankan bagaimana guru memperbaiki tatanan kalimat atau keutuhan paragraf dalam tulisan siswa meskipun ditemukan ada tulisan guru yang masih menunjukkan ketidakgramatikalan dan ketidakefektifan kalimat, ketidakutuhan paragraf, dan pelompatan ide antarkalimat atau antarparagraf.

Guru yang mampu menulis akan dapat mengajarkan siswanya menulis (Alwasilah, 2000). Sayangnya, dalam penelitian ini hanya tiga guru yang mengaku terbiasa menulis. Sisanya mengatakan belum mampu 
atau tidak menyukai menulis. Guru kurang terbiasa dan sangat terbatas menulis karena tidak ada tuntutan meskipun pengalaman mengajar guru terbanyak lebih dari dua puluh tahun (43.9\%) (lihat Tabel 8).

Kami tidak suka menulis karena tugas sudah banyak dan sudah lelah menulis persiapan mengajar dan soal-soal untuk siswa (perempuan, SDS)

Kami menulis hanya sebatas untuk mengajar saja. Pada saat menjelaskan tentang paragraf dan jenis karangan kami membuat contoh paragraf dan contoh karangan sediri. Kami belum sampai menulis dan mengirimkan tulisan ke media (perempuan, SDN)

Guru SD di Jakarta menunjukkan sikap positif terhadap bahasa tulis baku. Hasil ini tidak berbeda dengan penelitian sebelumnya dalam konteks akademik, seperti guru/dosen dan mahasiswa yang menunjukkan sikap positif terhadap penerimaan kata-kata serapan (Qodratillah dalam Sugiyono dan Sasangka, 2011); penulisan tanda baca dalam esai akademik (Hirvella et al., 2012). Sikap yang positif guru SD di Jakarta sudah ditunjukkan dengan perilakunya secara lisan kepada siswa agar siswa menggunakan bahasa Indonesia tulis formal dalam tulisannya, tetapi dalam praktiknya belum semua guru dapat menerapkannya dengan baik.

\section{Sikap Guru SD terhadap Bahasa Indonesia Tulis Baku menurut Jenis Sekolah}

Jika dilihat dari jenis sekolah, baik guru SDN maupun guru SDS memiliki sikap yang positif terhadap bahasa Indonesia $(<0.7)$. Indeks sikap guru SDN sebesar 0.787 dan indeks sikap bahasa guru SDS sebesar 0.771. Meskipun indeks sikap bahasa guru SDN lebih tinggi daripada indeks sikap bahasa guru SDS, hasil uji beda kedua indeks sikap bahasa tersebut menunjukkan tidak ada perbedaan yang signifikan di antara keduanya $(\mathrm{p}>0.10)$. Dengan demikian, jenis sekolah tidak membedakan sikap guru SD terhadap bahasa Indonesia. Dengan kata lain, positif-tidaknya sikap guru SD terhadap bahasa Indonesia tulis baku tidak bergantung pada jenis sekolah. Hal tersebut dapat diamati pada Tabel 12.

Tabel 12. Sikap Guru SD terhadap Bahasa Indonesia Tulis Baku menurut Jenis Sekolah

\begin{tabular}{lccccccc}
\hline & N & Mean & S.D. & T & Df & $\begin{array}{c}\text { Sig. (2- } \\
\text { tailed) }\end{array}$ \\
\hline \multirow{2}{*}{ Sikap } & SDN & 26 & .787 & .0715 & .847 & 47 & .401 \\
\cline { 2 - 5 } & SDS & 23 & .771 & .0639 & & & \\
\hline
\end{tabular}

Data pada Tabel 13 dapat dimaknai bahwa guru SDN dan guru SDS memiliki sikap yang sangat positif terhadap bahasa Indonesia pada komponen afektif $(>0.8)$, sementara pada komponen kognitif dan konatif mereka memiliki sikap yang positif $(<0.7)$. Selain itu, dapat dimaknai juga sikap guru SDN lebih positif daripada sikap guru SDS pada semua komponen sikap. Tabel 13 juga memperlihatkan bahwa indeks sikap guru
SDN lebih tinggi daripada indeks sikap guru SDS pada komponen kognitif, afektif, dan konatif. Perbandingan indeks sikap guru SDN dan SDS menunjukkan perbedaan yang tidak signifikan $(p>0.10)$ pada semua komponen. Dengan demikian, jika dilihat dari komponen kognitif, afektif, dan konatif sikap guru SD terhadap bahasa Indonesia tidak berbeda menurut jenis sekolah. 
Tabel 13. Sikap Guru SD terhadap Bahasa Indonesia Tulis Baku Menurut Komponen Sikap

\begin{tabular}{lccccccc}
\hline & \multicolumn{2}{c}{$\mathbf{N}$} & Mean & S.D. & T & Df & $\begin{array}{c}\text { Sig. (2- } \\
\text { tailed) }\end{array}$ \\
\hline \multirow{2}{*}{ Kognitif } & SDN & 27 & .800 & .07291 & .024 & 51 & .311 \\
\cline { 2 - 6 } Afektif & SDS & 26 & .779 & .0789 & & & \\
\cline { 2 - 6 } & SDN & 26 & .821 & .0843 & .615 & 51 & .541 \\
\hline \multirow{2}{*}{ Konatif } & SDN & 27 & .808 & .0613 & & & \\
\cline { 2 - 5 } & SDS & 30 & .719 & .0884 & & & .427 \\
\hline
\end{tabular}

Penelitian ini memperlihatkan bahwa asal sekolah guru tidak berpengaruh pada sikap positif guru terhadap bahasa Indonesia baku tulis. Dari profil guru tampak bahwa $93 \%$ guru SD (swasta dan negeri) berpendidikan S-1 meskipun di SDS ada $3.7 \%$ guru berpendidikan S-2 dan 10\% masih lulusan SMA. Latar belakang pendidikan guru sebanyak $83.3 \%$ dari jurusan pendidikan. Selain itu, guru senior yang mengajar lebih dari dua puluh tahun mencapai $43.9 \%$ dan hampir separuh (56.1\%) menggunakan bahasa ibu bahasa Indonesia. Data ini memperlihatkan bahwa guru dari asal sekolah swasta atau negeri sudah sangat berpengalaman mengajar, sudah memenuhi kualifikasi sebagai guru dengan jenjang akademik yang dianutnya, dan tidak banyak menggunakan bahasa daerah (umumnya Jawa, lihat Tabel 9).

Yang perlu ditelisik lebih jauh adalah bagaimana sikap siswa dari kedua jenis sekolah (swasta dan negeri) dalam menggunakan bahasa Indonesia baku tulis. Apakah sikapnya sama positifnya dengan sikap gurunya? Penelitian yang pernah dilakukan Liando (2012) terhadap kelas regular dan bilingual dalam satu sekolah di Manado memperlihatkan ada perbedaan signifikan dalam hasil belajar bahasa Inggris sebagai bahasa kedua. Bedanya dengan penelitian ini adalah bahasa Indonesia bukan sebagai bahasa kedua, melainkan bahasa pertama yang digunakan di kelas regular.

\section{SIMPULAN}

Jenjang pendidikan dasar merupakan fondasi penanaman nilai-nilai, termasuk sikap terhadap bahasa yang digunakan. Sikap positif terhadap bahasa Indonesia perlu ditanamkan kepada siswa sejak di SD. Sikap ini dapat ditularkan oleh guru SD sebagai model dalam berbahasa dan berperilaku kepada siswa, khususnya dalam pemakaian bahasa Indonesia baku. Penelitian ini menemukan bahwa guru memiliki sikap positif terhadap bahasa Indonesia tulis baku. Dipandang dari jenis sekolah, tidak ada perbedaan antara guru SDN dan SDS di DKI Jakarta terhadap sikap positif guru dalam berbahasa Indonesia tulis baku. Sikap positif guru ini dapat diamati dari perilakunya yang tersurat dalam tulisan dan wawancara.

Guru SD di Jakarta memiki rasa setia dan bangga menggunakan bahasa Indonesia. Ini dibuktikan dengan seringnya guru menegur dan mengoreksi tulisan siswa, terutama tanda baca, ketika menulis. Dengan menguasai kaidah bahasa, sikap guru yang positif terhadap bahasa Indonesia bukan hanya ditunjukkan melalui imbauan kepada siswa, melainkan juga kemampuannya meningkatkan profesionalitas sebagai guru pembelajar yang memahami kaidah bahasa Indonesia dengan cara mampu menerapkan kaidah-kaidah tersebut ke dalam tulisan. Dengan demikian, guru dapat memberi contoh dan memotivasi siswa agara menulis lebih baik. 
Penelitian ini memiliki keterbatasan dalam hal jenis kelamin responden. Penelitian ini menggunakan jumlah responden laki-laki dan perempuan yang tidak sebanding: 10 lakilaki dan 47 perempuan. Diharapkan penelitian selanjutnya dapat melibatkan jumlah guru lakilaki dan perempuan yang sebanding dan memperluas jangkauan penelitian hingga ke beberapa kota di Indonesia. Penelitian berikutnya juga dapat lebih mendalami bagaimana sikap siswa SDS dan SDN dalam pemelajaran bahasa Indonesia tulis atau membandingkan penggunaan bahasa dan gender antarsiswa di SDS dan SDN.

\section{DAFTAR RUJUKAN}

Alwasilah, A. C. (2000). Membenahi perkuliahan MKDU bahasa Indonesia di perguruan tinggi. In Kajian serba linguistik untuk. Anton Moeliono (pp. 677691). Jakarta: BPK Gunung Mulia.

Asih. (2016). Strategi Pembelajaran Bahasa Indonesia. Bandung: Pustaka Setia.

Basuki, Suryani, Y. E. S., \& Setiyadi, D. B. P. (2015). Kesulitan belajar siswa dalam pembelajaran bahasa Indonesia. Prosiding Simposium Nasional Riset Pendidikan II, 364-370.

Daryanto, \& Tasrial. (2015). Pengembangan Karir Profesi Guru. Yogyakarta: Gava Media.

Fasold, R. (1984). The Sociolinguistics of Society. England: Basil Blackwell.

Jakaria, Y. (2014). Analisis kelayakan dan kesesuaian antara latar belakang pendidikan guru sekolah dasar dengan mata pelajaran yang diampu. Jurnal Pendidikan dan Kebudayaan, 20, 4, 499514.

Keragaman bahasa di Jakarta. Retrived January, 24.2016. http://jakartapedia.bpadjakarta.net/in dex.php/Keragaman Bahasa Di Jaka $\underline{\text { rta }}$

Kobayashi, Y. (2002). The role of gender in foreign language learning attitude: Japanesse female student attitudes towards English learning. Gender and Education, 14, 2, 181-197.
Kompas. (2016, Oktober). Wapres: Benahi pendidikan guru. Jakarta.

Kompas. (2015, 8 Juli). Kualitas guru masih rendah. Jakarta.

Kridalaksana, H. (2001). Kamus Linguistik. Jakarta: Gramedia Pustaka Utama.

Liando, N.V.F. (2012). Bilingual and regular class students'attitudes towards English. Litera, 11, 2, 267--273.

Matanggui, J. \& E. Zaenal Arifin. (2014). Analisis Kesalahan Berbahasa Indonesia. Jakarta: Pustaka Mandiri.

Moeliono, A. M., Puspita, D., \& Afrila, M. (2011). Butir-Butir Perencanaan Bahasa: Kumpulan Makalah Dr. Hasan Alwi. Jakarta: Badan Pengembangan dan Pembinaan Bahasa Kementerian Pendidikan dan Kebudayaan .

Moeliono, L. (2013). Analisis Data Kualitatif (ADK). Seri Mata Kuliah Metodologi Penelitian. Jakarta: Studio Teknologi Pendidikan-Perpustakaan.

Mustakim. (1997). Sikap kalanga perguruan tinggi di Jakarta terhadap kosakata baru bahasa Indonesia. Bahasa dan Sastra, XV, 6, 1--25.

Ruddyanto, C. (2011). Mencari penutur model bahasa Indonesia: Guru, birokrat, dan jurnalis. Pemberdayaan Bahasa Indonesia Memperkukuh Budaya Bangsa dalam Era Globalisasi. Risalah Kongres Bahasa Indonesia VIII, 239-248.

Sugiyono \& Sasangka, S. S. (2011). Sikap Masyarakat Indonesia terbadap Bahasanya. Yogyakarta: Elmatera Publishing.

Sumarsono. (2000). Sikap dan konatif tutur penutur bahasa Melayu Loloan terhadap bahasanya dan bahasabahasa lainnya. In Kajian Serba Linguistik untuk. Anton Moeliono Pereksa Bahasa. Jakarta: Universitas Katolik Indonesia Atma Jaya dan PT BPK Gunung Mulia.

Tsui, A.B.M. \& Bunton, A.D. (2000). The discourse and attitude of English teachers in Hong Kong. World Englishes, 19, 1, 287-303.

Sukma, R. (2016). Inferioritas dan sikap bahasa remaja di Jakarta terhadap 
bahasa Betawi atau bahas ibu dalam ranah masyarakat multilingual. Kumpulan makalah Kongres Internasional Masyarakat Linguistik Indonesia. Universitas Udayana, Denpasar.

Suroso. (2015). Membarukan penguasaan kebahasaan bagi guru. Retrieved January $\quad 14, \quad 2017$, http://staffuny.ac.id/sites/default/file s/penelitian

Wang, L. \& Ladegaard, H.J. (2008). Language attitude and gender in China: Perception and reported use of Putonghua and Cantonese in the Southern Province of Guandong. Language Awareness, 17, 1, 57-77.

\section{UCAPAN TERIMA KASIH}

Peneliti menghaturkan terima kasih kepada responden guru SD DKI di Jakarta, juga kepada Lembaga Penelitian dan Pengabdian kepada Masyarakat Unika Atma Jaya, Jakarta, yang telah mendanai penelitian Jakarta in Focus ini. 